Supporting Information

\title{
Uniform deposition of Li-metal anode guided by 3D current collector with in situ modification of lithiophilic matrix
}

Chenyi Sun+, Yinghui Yang ${ }^{+}$, Xiufang Bian*, Rongzhang Guan, Chao Wang, Dujiang Lu, Li Gao, and Dongmei Zhang

Key Laboratory for Liquid-Solid Structural Evolution and Processing of Materials, Ministry of Education, Shandong University, Jinan 250061, China

* E-mail: xfbian@sdu.cn 

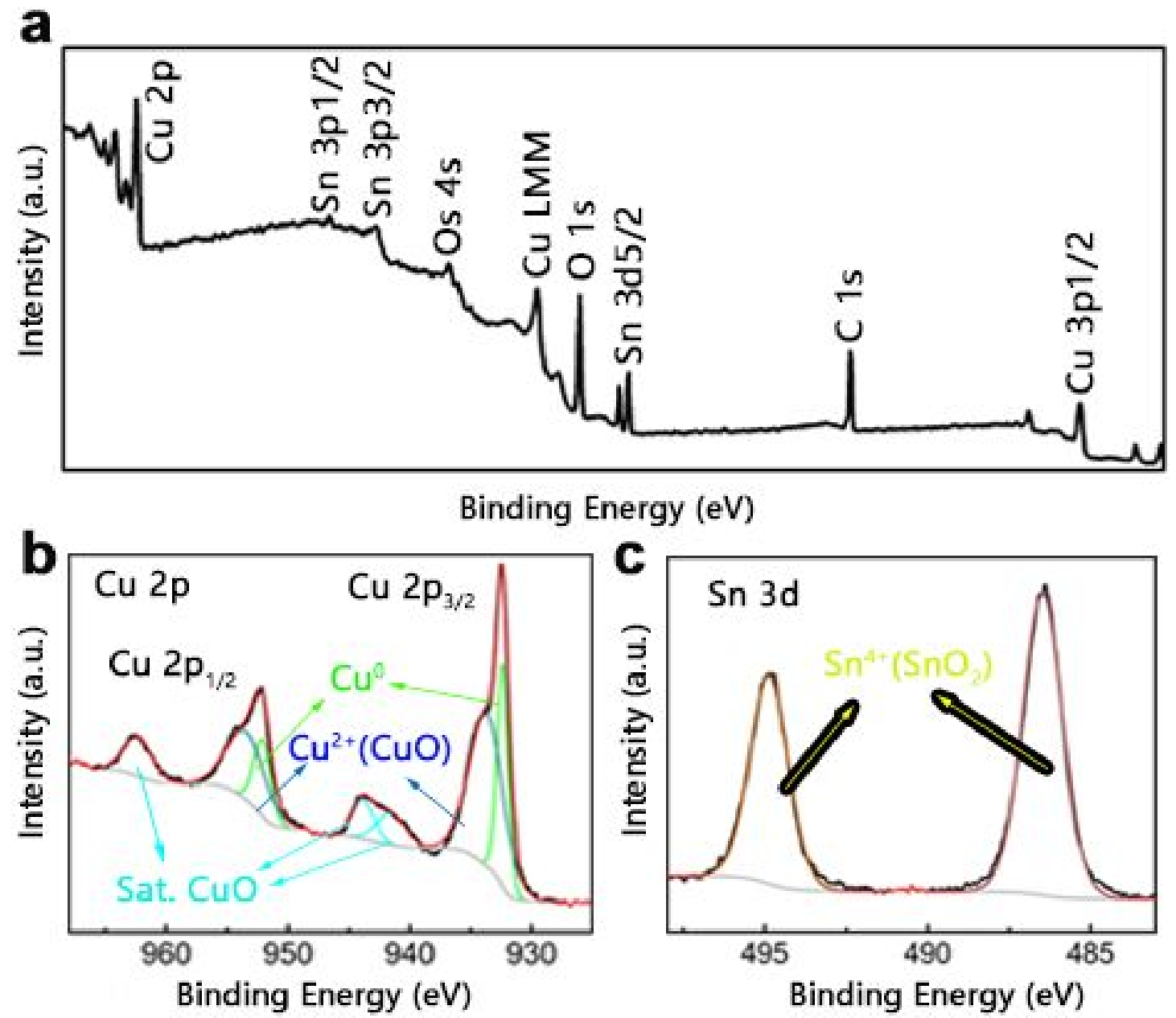

Figure S1. The XPS survey spectrum of 3D CSCC. 

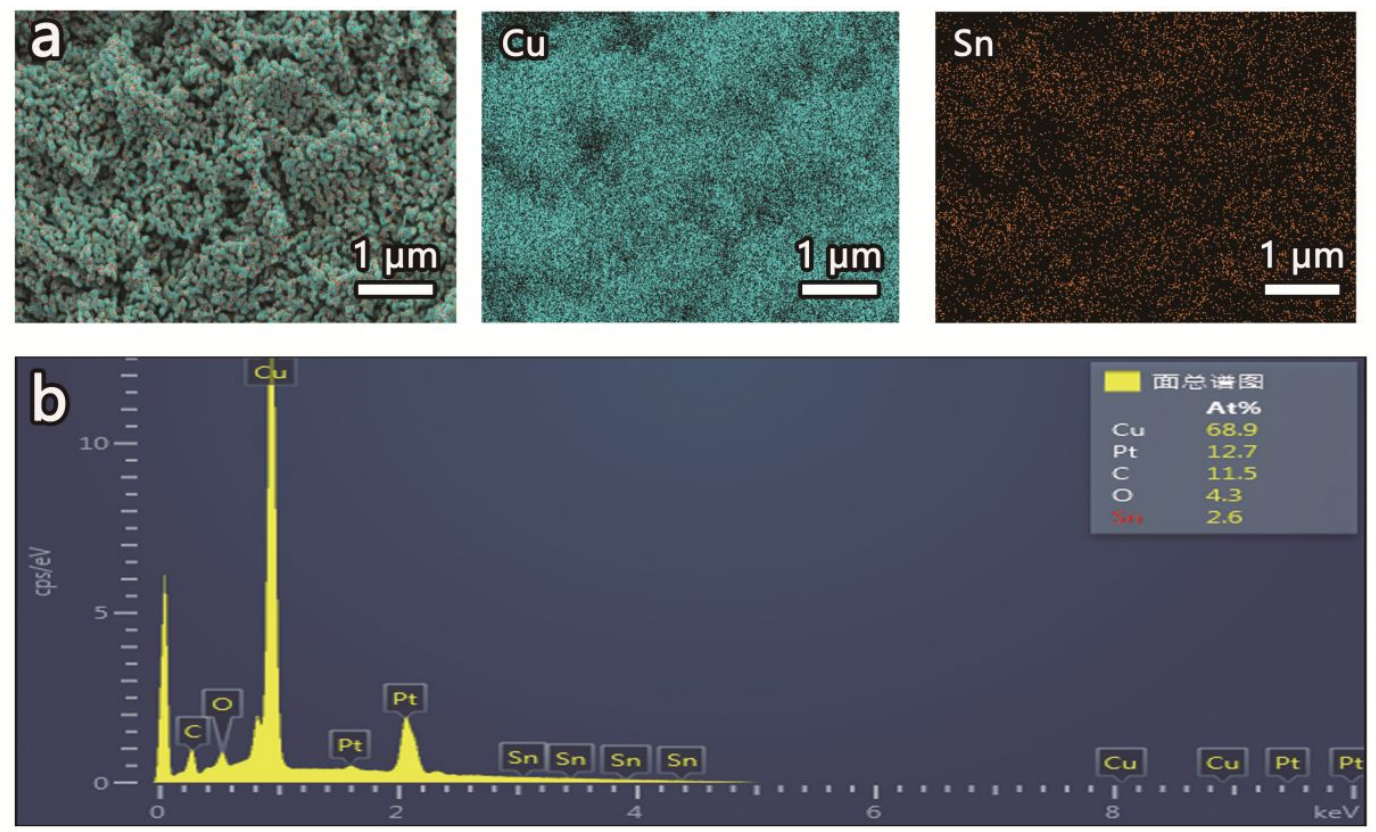

Figure S2. The EDS mapping images of 3D CSCC.
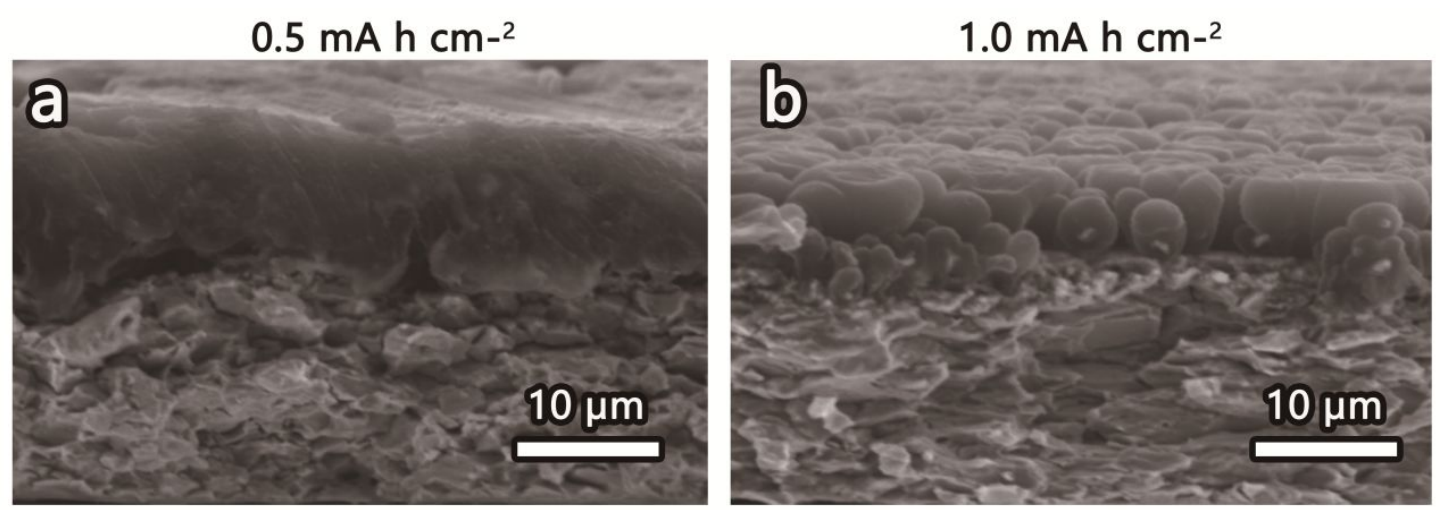

\section{$1.5 \mathrm{~mA} \mathrm{~h} \mathrm{~cm}^{-2}$}

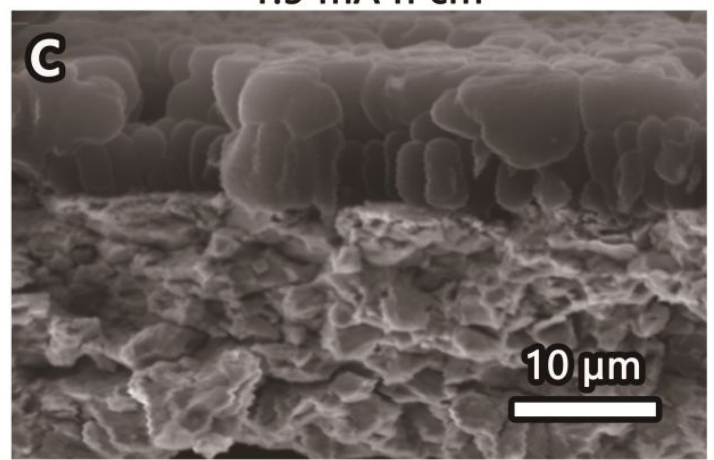

\section{$2.0 \mathrm{~mA} \mathrm{~h} \mathrm{cm-2}^{2}$}

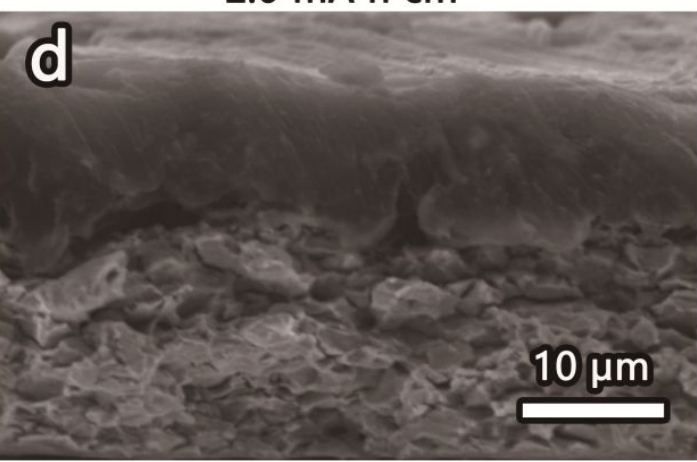

Figure S3. SEM images of various amounts of Li plating in 3D CSCC with a current density of $1.0 \mathrm{~mA} \mathrm{~cm}^{-2}$; (a) $0.5 \mathrm{~mA} \mathrm{~h} \mathrm{~cm}^{-2}$; (b) $1.0 \mathrm{~mA} \mathrm{~h} \mathrm{~cm}^{-2}$; (c) $1.5 \mathrm{~mA} \mathrm{~h} \mathrm{~cm}$; ; (d) $2.0 \mathrm{~mA} \mathrm{~h} \mathrm{~cm}^{-2}$. 

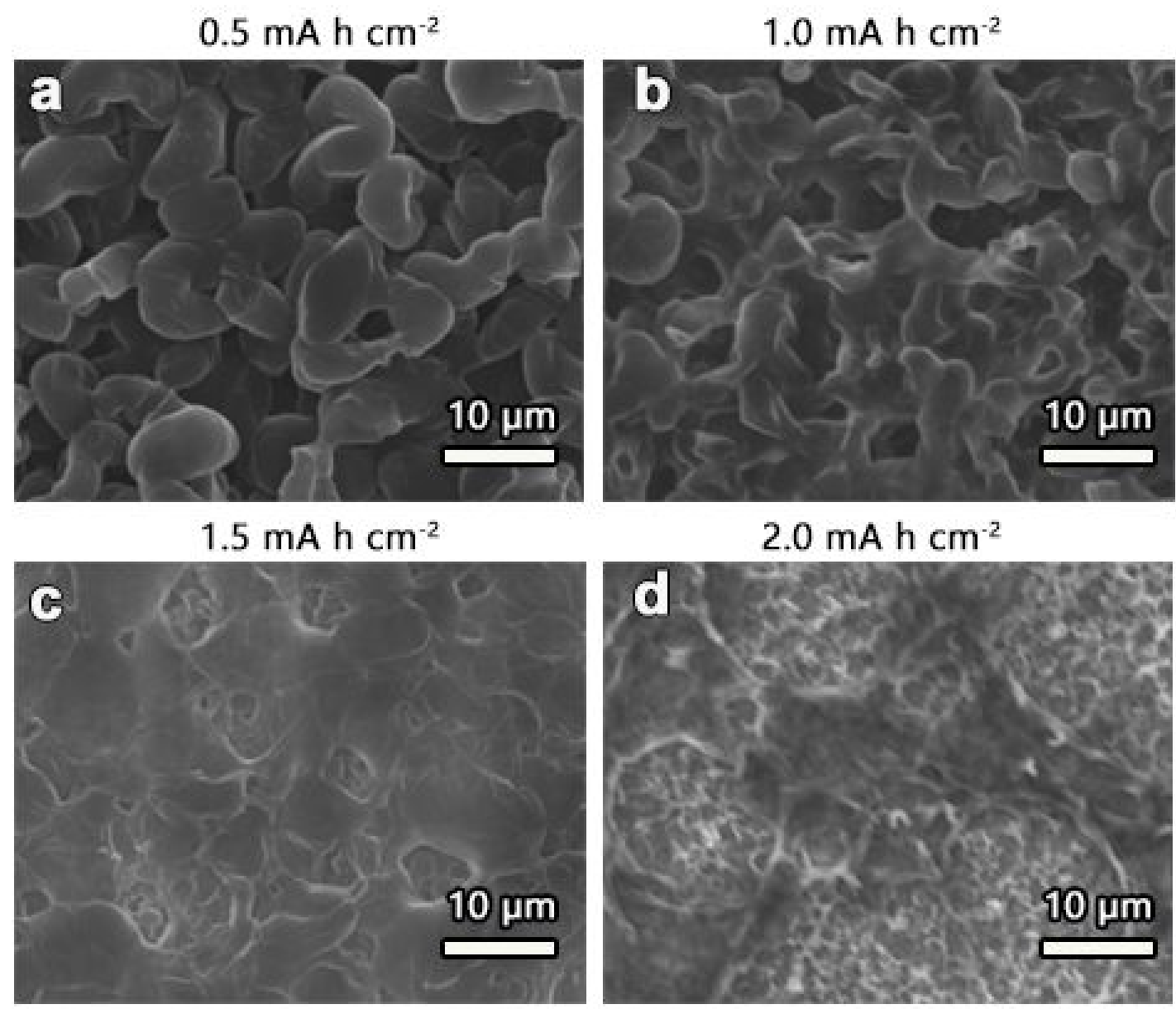

Figure S4. SEM images of various amounts of Li stripping in $\mathrm{Cu}$ foil with a current density of $1.0 \mathrm{~mA} \mathrm{~cm}^{-2}$; (a) $0.5 \mathrm{~mA} \mathrm{~h} \mathrm{~cm}{ }^{-2}$; (b) $1.0 \mathrm{~mA} \mathrm{~h} \mathrm{~cm}{ }^{-2}$; (c) $1.5 \mathrm{~mA} \mathrm{~h} \mathrm{~cm}$; (d) $2.0 \mathrm{~mA} \mathrm{~h} \mathrm{~cm}^{-2}$. 


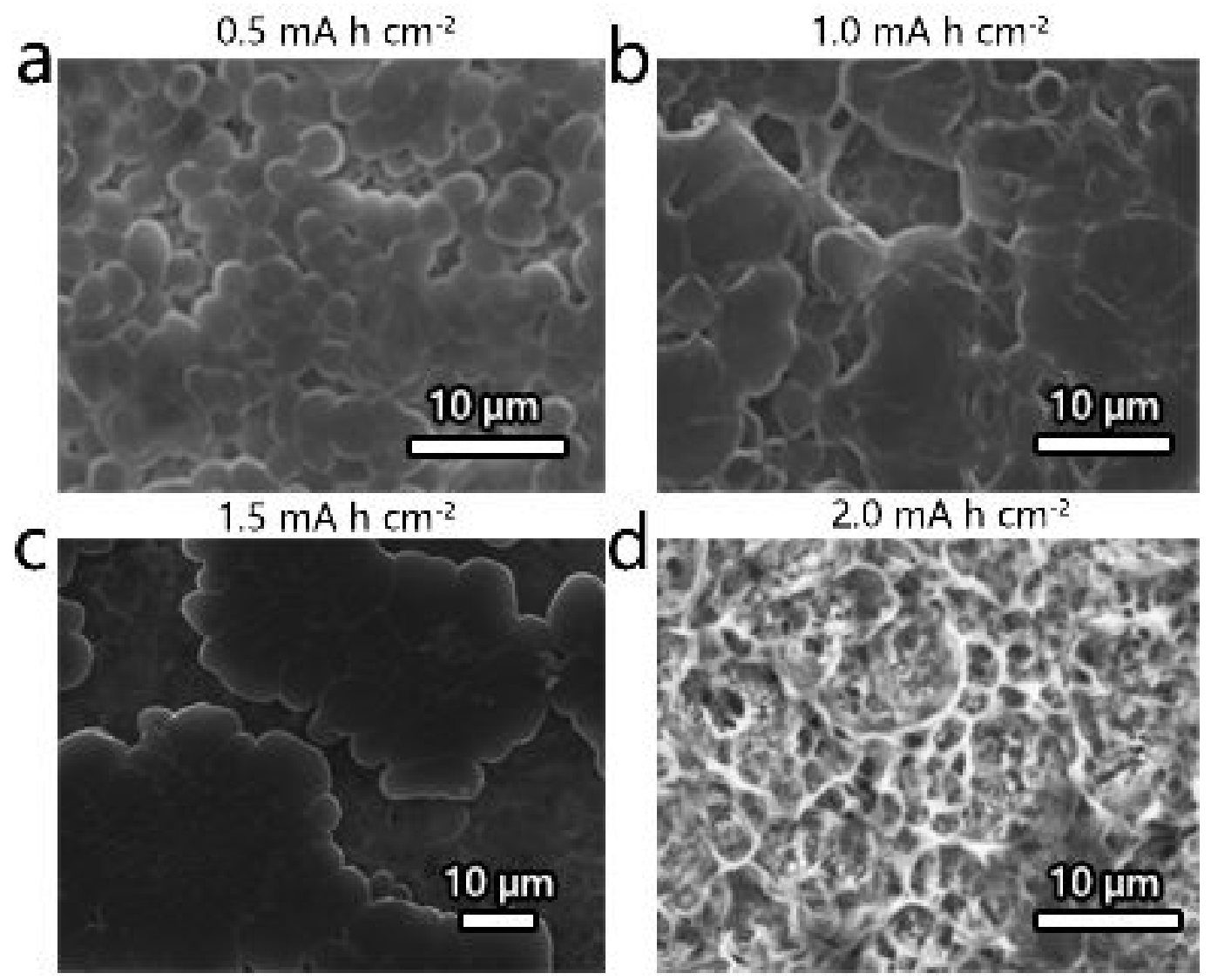

Figure S5. SEM images of various amounts of Li stripping in 3D CSCC with a current density of $1.0 \mathrm{~mA} \mathrm{~cm}^{-2}$; (a) $0.5 \mathrm{~mA} \mathrm{~h} \mathrm{~cm}$; ; (b) $1.0 \mathrm{~mA} \mathrm{~h} \mathrm{~cm}$; ; (c) $1.5 \mathrm{~mA}$ $\mathrm{h} \mathrm{cm}^{-2}$; (d) $2.0 \mathrm{~mA} \mathrm{~h} \mathrm{~cm}{ }^{-2}$. 


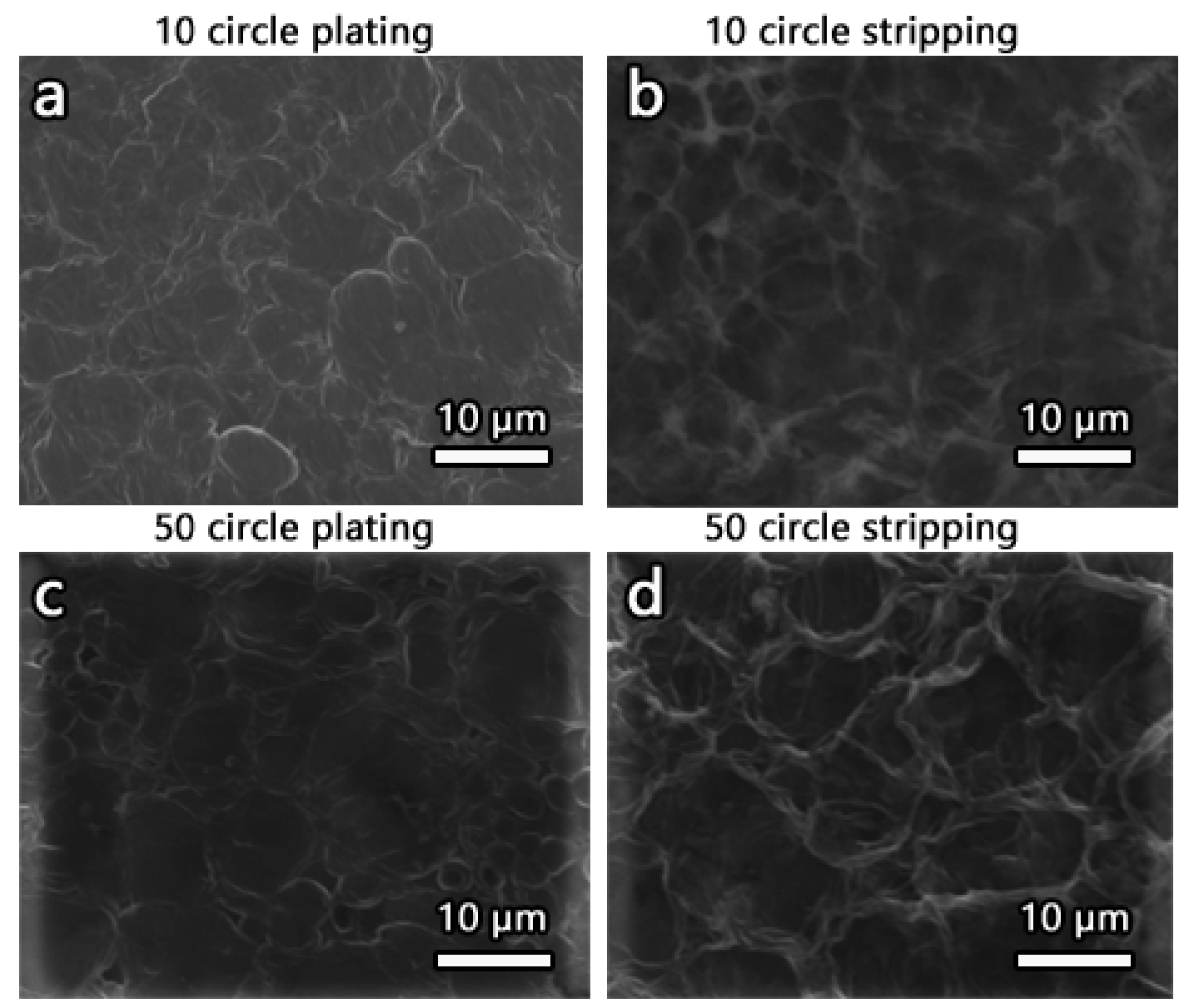

Figure S6. The plating/stripping SEM images of 10 and 50 cycles in 3D CSCC at a current density of $1.0 \mathrm{~mA} \mathrm{~cm}{ }^{-2}$ with a density of $1.0 \mathrm{~mA} \mathrm{~h} \mathrm{~cm} \mathrm{~cm}^{-2}$. 

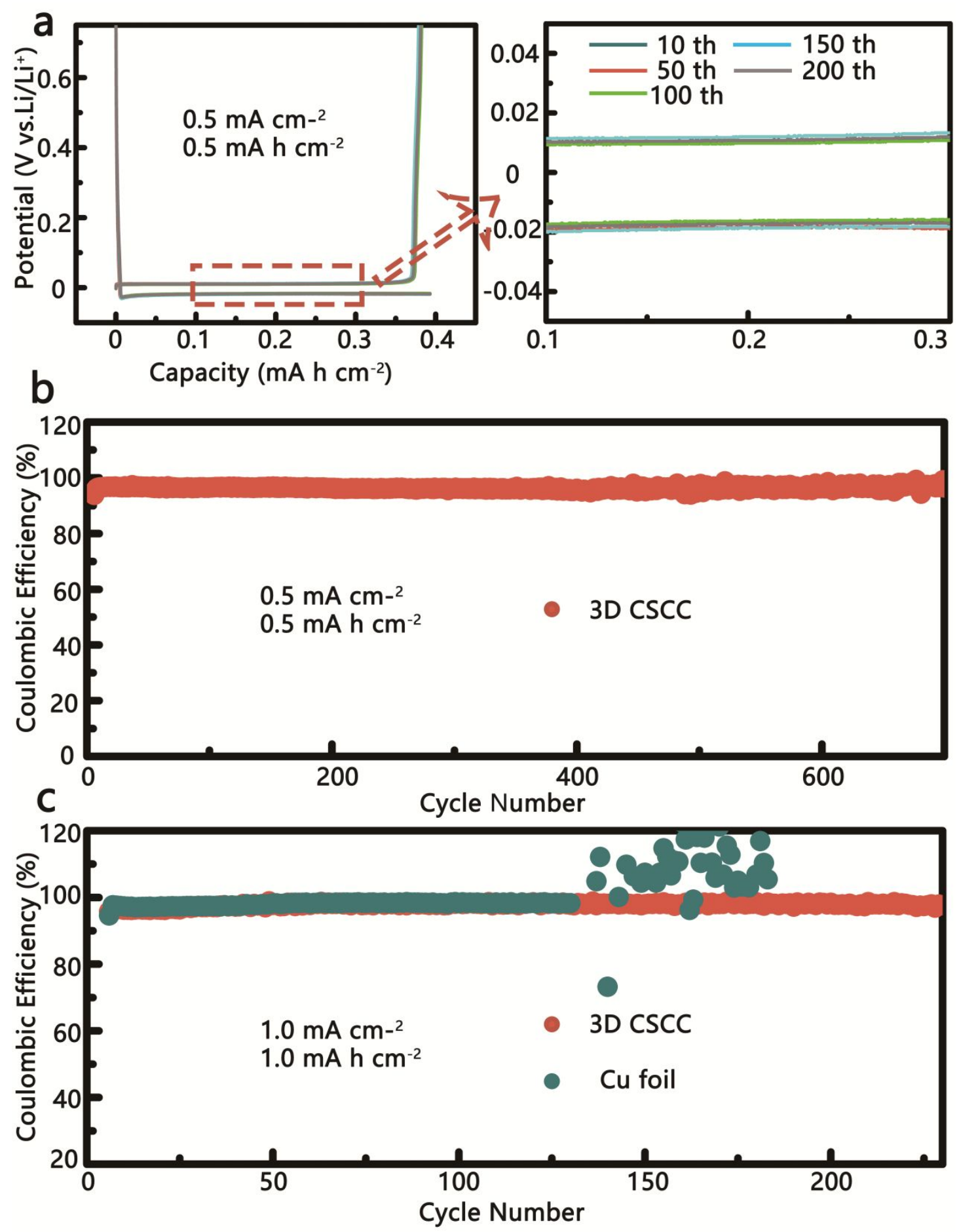

Figure S7. (a) The 10th, 50th, 100th, 200th circles of Voltage profiles of Li plating/stripping on 3D CSCC at a current density of $0.5 \mathrm{~mA} \mathrm{~cm}{ }^{-2}$ with a capacity of $0.5 \mathrm{~mA} \mathrm{~h} \mathrm{~cm} \mathrm{~m}^{-2}$. The coulombic efficiency of Li plating/stripping on 3D CSCC current collector samples with current density (b) of $0.5 \mathrm{~mA} \mathrm{~cm}{ }^{-2}$ for $0.5 \mathrm{~mA} \mathrm{~h}$ $\mathrm{cm}^{-2}$ and on 3D CSCC and $\mathrm{Cu}$ foil current collector samples at current densities (c) of $1.0 \mathrm{~mA} \mathrm{~cm}^{-2}$ with a Li capacity of $1 \mathrm{~mA} \mathrm{~h} \mathrm{~cm}{ }^{-2}$. 

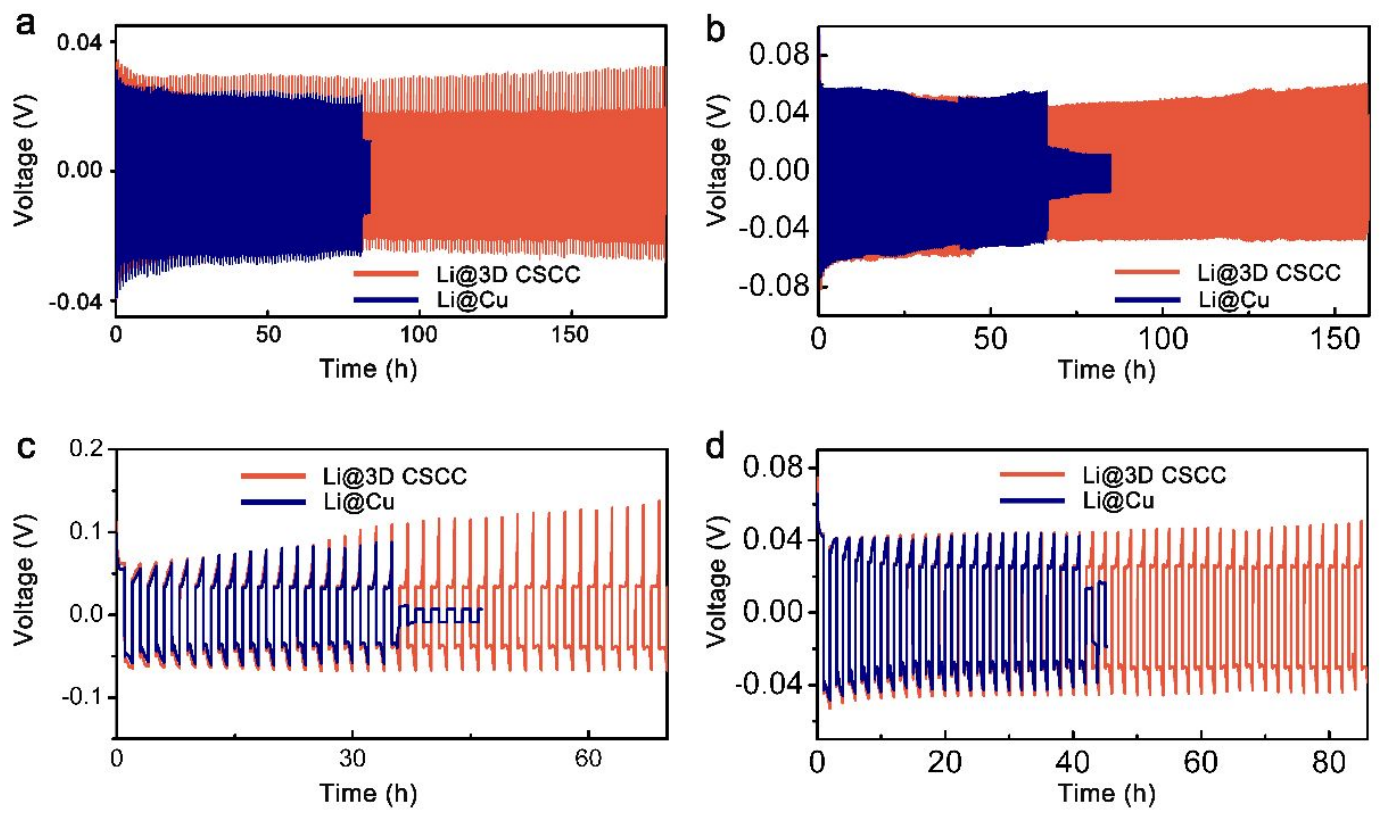

Figure S8. Voltage-time profiles of Li-pated plane 3D CSCC and $\mathrm{Cu}$ foil current collector $\mathrm{Li} \| \mathrm{Li}$ symmetric cell at current density of (a) $2.0 \mathrm{~mA} \mathrm{~cm} \mathrm{~cm}^{-2} 1.0 \mathrm{~mA} \mathrm{~h}$ $\mathrm{cm}^{-2}$, (b) $3.0 \mathrm{~mA} \mathrm{~cm}-21.0 \mathrm{~mA} \mathrm{~h} \mathrm{~cm}{ }^{-2}$, (c) $3.0 \mathrm{~mA} \mathrm{~cm}{ }^{-2} 3.0 \mathrm{~mA} \mathrm{~h} \mathrm{~cm}{ }^{-2}$, (d) $2.0 \mathrm{~mA}$ $\mathrm{cm}^{-2} 2.0 \mathrm{~mA} \mathrm{~h} \mathrm{~cm}^{-2}$. The 3D CSCC current collector and $\mathrm{Cu}$ foil electrodes were pre-deposited $5.0 \mathrm{~mA} \mathrm{~h} \mathrm{~cm}^{-2} \mathrm{Li}$.

$1.0 \mathrm{~mA} \mathrm{~cm}^{-2} 1.0 \mathrm{~mA} \mathrm{~h} \mathrm{~cm}{ }^{-2}$
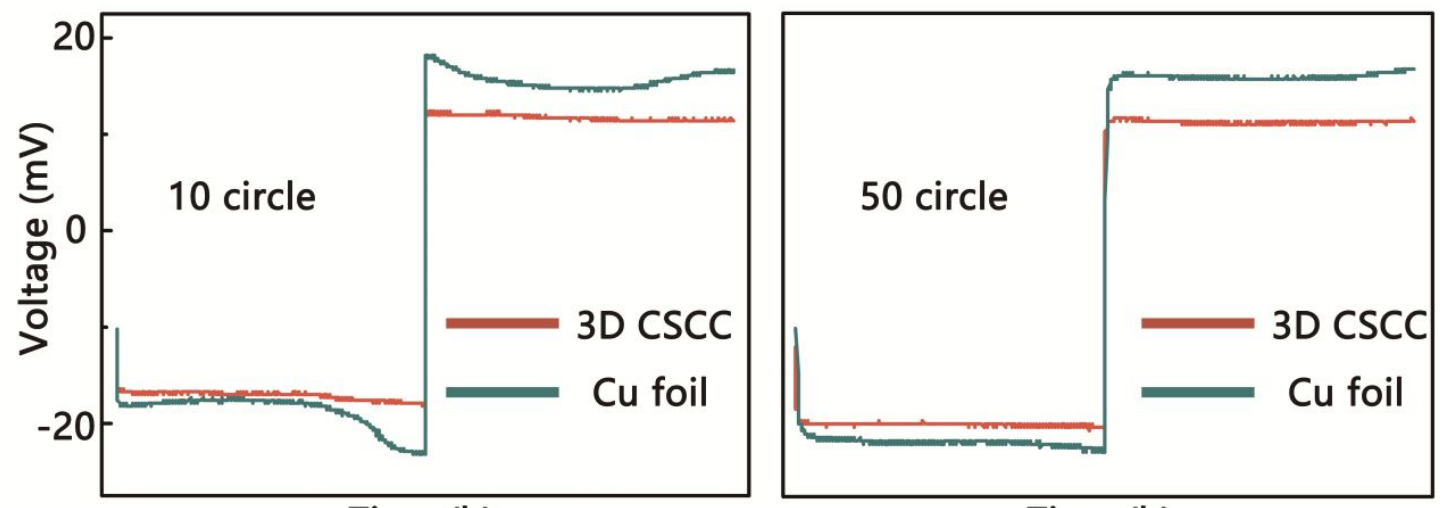

Time (h)

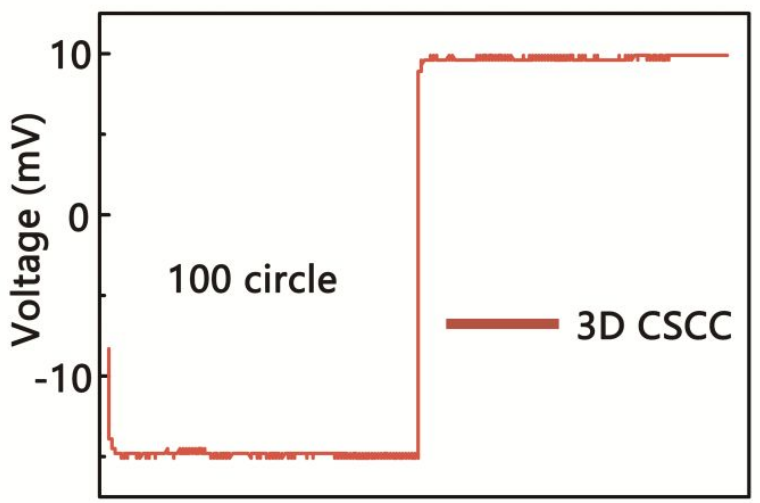

Time (h)
Time (h)

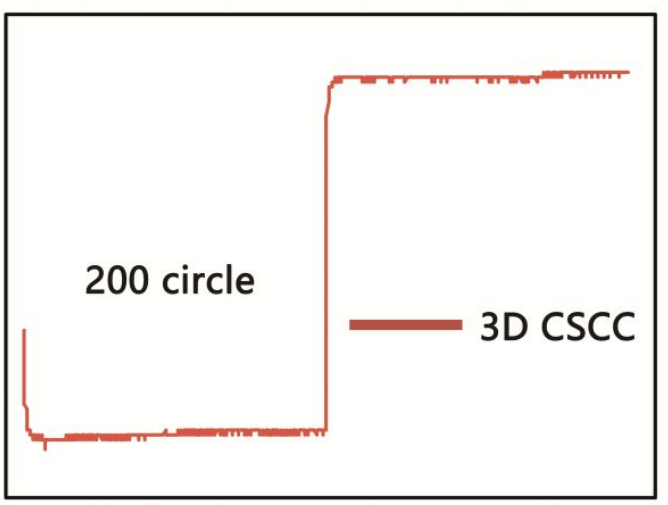

Time (h)

Figure S9. Detailed voltage profiles of 3D CSCC and $\mathrm{Cu}$ foil current collector 
electrodes in symmetric cells at a current density of $1.0 \mathrm{~mA} \mathrm{~cm}{ }^{-2}$ with a capacity of

1.0

$\mathrm{mA}$

$\mathrm{h}$

$\mathrm{cm}^{-2}$.

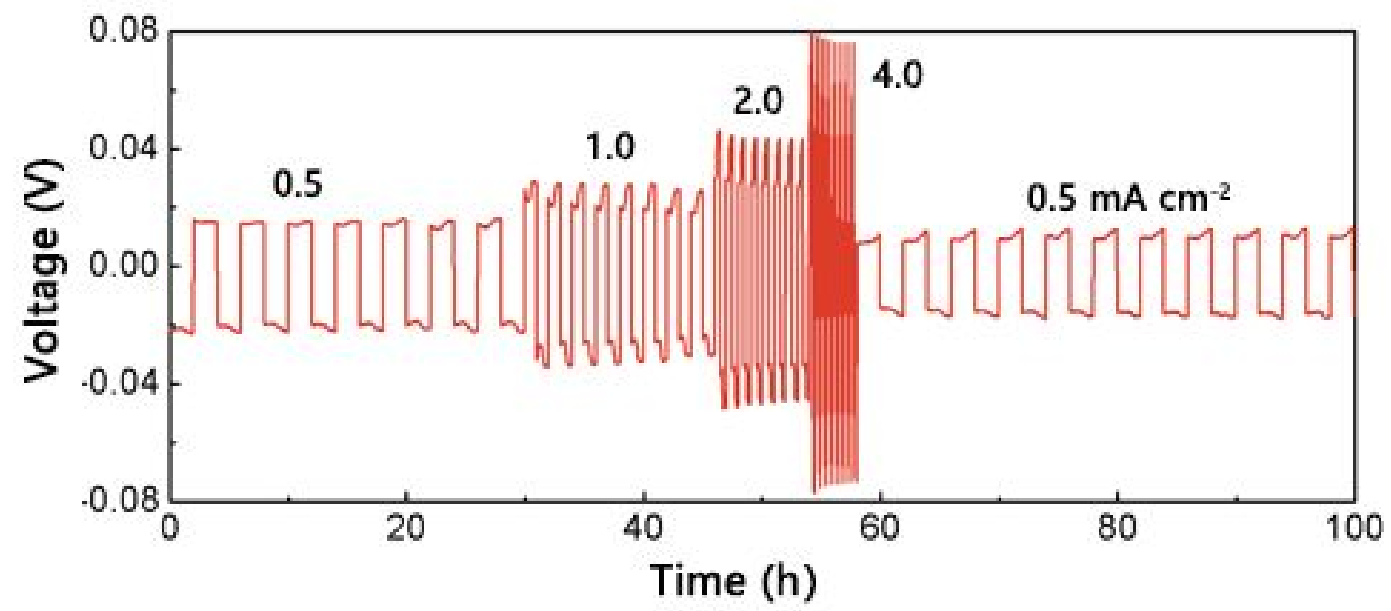

Figure S10. Voltage profiles of Li-plated Li@3D CSCC || $\mathrm{Li}$ symmetric cell at increasing current densities from 0.5 to $1.0,2.0,4.0 \mathrm{~mA} \mathrm{~cm}^{-2}$ for $1.0 \mathrm{~mA} \mathrm{~h} \mathrm{~cm}{ }^{-2}$ capacity

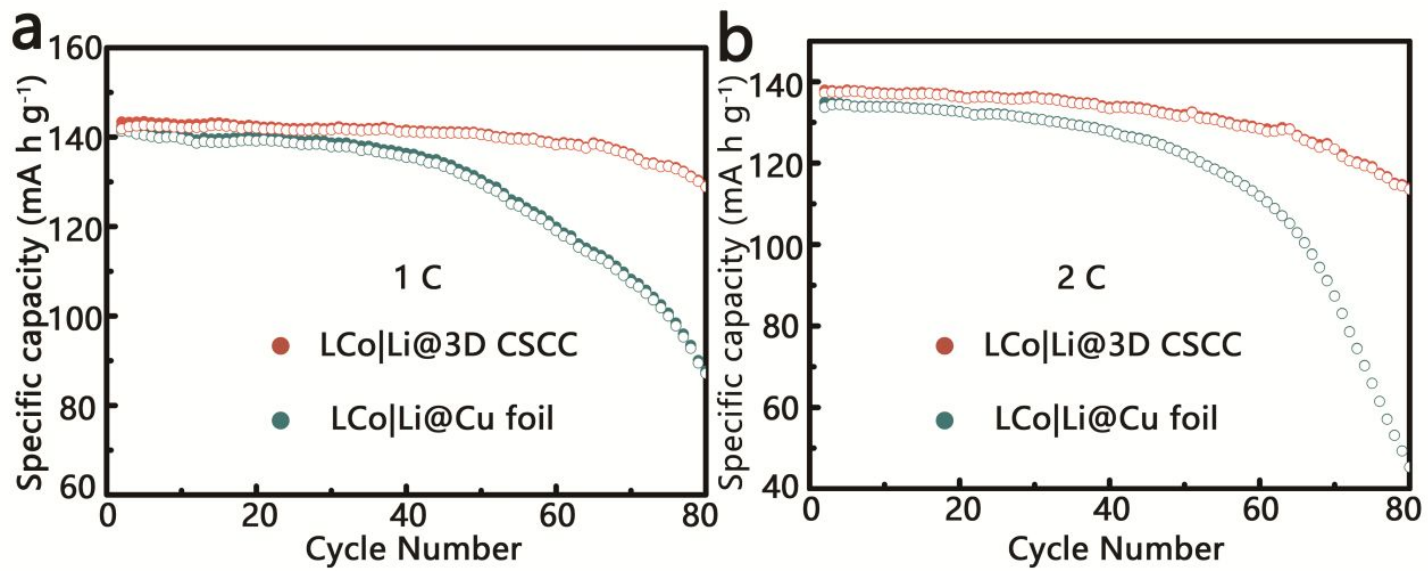

Figure S11. ( $\mathrm{a}$ and b) Cycling performances of LCo||Li@3D CSCC cells at a rate of $1 \mathrm{C}$ and $2 \mathrm{C}$. 

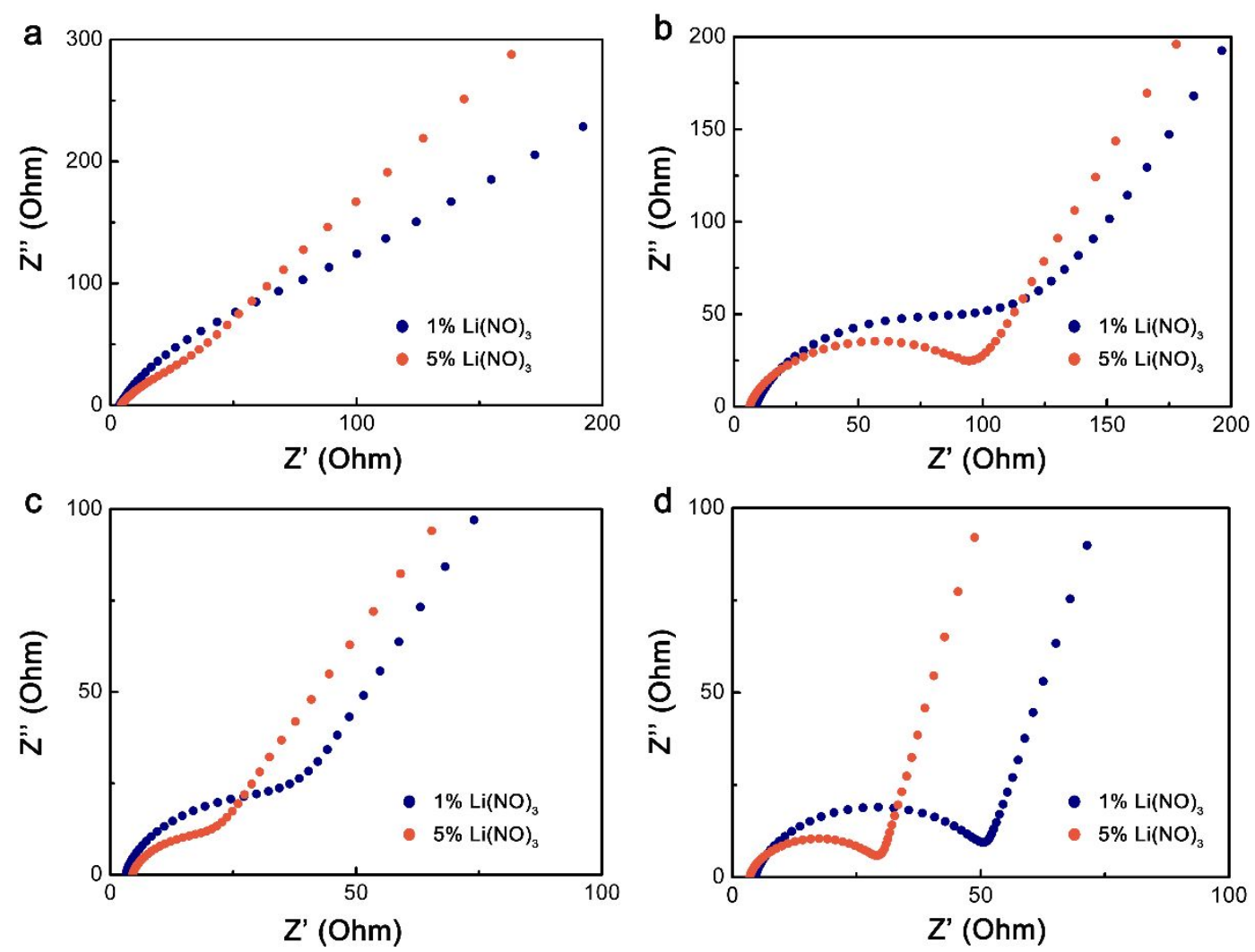

Figure S12. Electrochemical impedance spectroscopy (EIS) of 3D CSCC and $\mathrm{Cu}$ foil current collector in different electrolyte. (a) $\mathrm{Cu}$ before activization, (b) $\mathrm{Cu}$ after activization, (c) 3D CSCC befor activization, (d) 3D CSCC after activization.

a

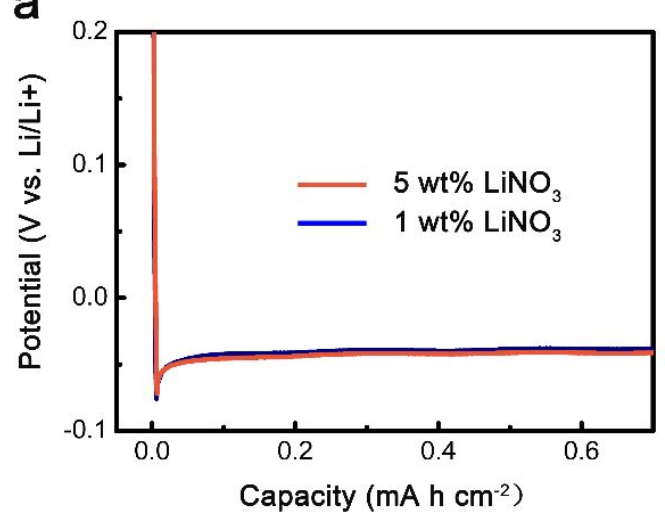

b

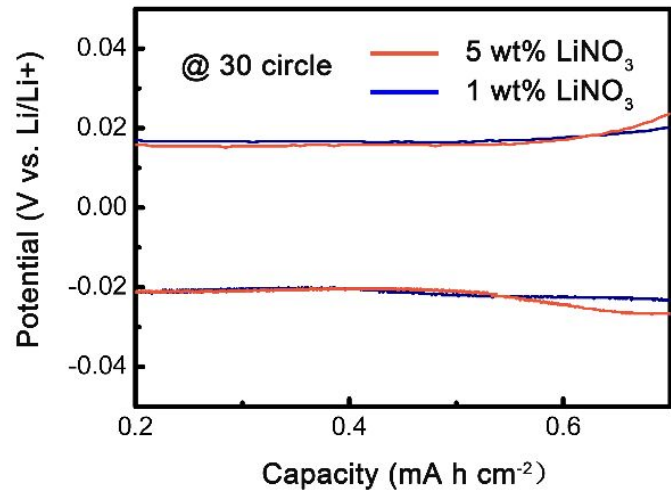

Figure S13. (a) Voltage profiles of Li plating on 3D CSCC with a capacity of 1.0 $\mathrm{mA} \mathrm{h} \mathrm{cm}{ }^{-2}$ at a current density of $1.0 \mathrm{~mA} \mathrm{~cm}^{-2}$ in different electrolyte. (b) The 30th cycle of galvanostatic plating/stripping voltage profiles of Li $\| 3 \mathrm{D}$ CSCC cell with a capacity of $1.0 \mathrm{~mA} \mathrm{~h} \mathrm{~cm}-2$ at a current density of $1.0 \mathrm{~mA} \mathrm{~cm}^{-2}$ in different electrolyte. 